\title{
Characterization of a novel hatching enzyme purified from starfish Asterina pectinifera
}

\author{
Ji Hoon Choi and Sang Moo Kim*
}

\begin{abstract}
Hatching enzyme is a protease which can degrade the membrane of egg. In this study, a hatching enzyme was purified from starfish (Asterina pectinifera) with 6.34 fold of purification rate, $5.04 \%$ of yield, and $73.87 \mathrm{U} / \mathrm{mg}$ of specific activity. The molecular weight of starfish hatching enzyme was $86 \mathrm{kDa}$, which was reduced to $62 \mathrm{kDa}$ after removal of $\mathrm{N}$-linked oligosaccharides. The optimal pH and temperature of the hatching enzyme activity were $\mathrm{pH} 7.0$ and $40^{\circ} \mathrm{C}$, respectively, while those of stability were $\mathrm{pH} 8$ and $20^{\circ} \mathrm{C}$. The kinetic parameters, $V_{\text {max }}, K_{m}, K_{\text {cat }}$ and $K_{\text {cat }} / K_{m}$ values were $0.197 \mathrm{U} / \mathrm{ml}, 0.289 \mathrm{mg} / \mathrm{ml}, 112.57 \mathrm{~s}^{-1}$, and $389.52 \mathrm{ml} / \mathrm{mg}$ s, respectively. $\mathrm{Zn}^{2+}$ increased the enzyme activity by $167.28 \%$, while EDTA, TPCK, TGCK, leupeptin, PMSF, and TLCK decreased. In addition, $\mathrm{Ca}^{2+}, \mathrm{Mg}^{2+}$, and $\mathrm{Cu}^{2+}$ did not affect the enzyme activity. The starfish hatching enzyme activity pretreated with EDTA was recovered by $\mathrm{Zn}^{2+}$. Therefore, the starfish hatching enzyme was classified as a serine-zinc protease.
\end{abstract}

Keywords: Deglycosylation, Hatching enzyme, Purification, Serine-zinc protease, Starfish, Asterina pectinifera

\section{Background}

Hatching enzyme is a protease released from hatching gland cells in hatching embryos for digesting their protective extracellular coats (Lepage and Gache 1989; Fan and Katagiri 2001; Yasumasu et al. 1989a, b). The hatching enzyme can provide a typical model in the studies of certain cell differentiation, specific protein synthesis, and special gene expression regulation during a certain stage of early embryos at the morphological and molecular level (Fan et al. 2010). The hatching enzymes from many animal species, such as echinoderm (Lepage and Gache 1989), mammalian (Sawada et al. 1990), avians (Yasumasu et al. 2005), amphibians (Fan and Katagiri 2001; Kitamura and Katagiri 1998; Urch and Hedrick 1981), teleostean (Yasumasu et al. 1989a, b; Kudo et al. 2004; Shi et al. 2010), and insect (Young et al. 2000), have been studied since 1980s. Several marine hatching enzymes have been identified as a metalloprotease from a variety of marine species; brine shrimp Artermia

*Correspondence: smkim@gwnu.ac.kr

Department of Marine Food Science and Technology, Gangneung-Wonju National University, 7 Jukheon-gil, Gangneung 25457, Republic of Korea salina (Fan et al. 2010), flounder Paralichthys olivaceus (Shi et al. 2010), shrimp Penaeus chinensis (Li et al. 2006), and sea squirt Ciona intestinalis (D'Aniello et al. 1997), whereas the sea urchin hatching enzyme is classified as a collagenase-like (EC 3.4.24.12) enzyme. The hatching enzymes were involved in many physiological processes such as cell migration, tissue repair, angiogenesis, inflammation, tumor invasion, and metastasis ( $\mathrm{Li}$ and Kim 2013; Roe and Lennarz 1990).

Collagens compose about $70 \%$ human skin, where the predominant ones are types I (80-90\%) and III (10$15 \%$ ) (Ala-Kokko et al. 1987). Hence, collagenases have been used for pharmacological purpose to treat various collagen mediated diseases such as keloid and scar, which are caused by over accumulation of collagen in tissue.

Starfish is an invertebrate belonging to the class of Asteroidea, Phylum Echinodermata, which produces a variety of secondary metabolites including steroids glycosides, anthraquinones, alklaoids, phospholipids, peptides, and fatty acids (Barkhouse et al. 2007; Kurihara 1999). However, starfish has been regarded as a harmful marine animal to marine ecosystem because it causes severe loss of mussel, oyster, scallop, etc. Therefore, many 
countries including Korea spend a lot of budget to relieve their marine ecosystem by reducing the number of starfish. In our previous studies (Li and Kim 2013, 2014a, b), a novel hatching enzyme was purified and characterized from starfish Asterias amurensis, which has habitat in the Ocean of East Russian. However, Asterin apectinifera starfish is predominant in the Ocean of Korean peninsula. Therefore, the objective of this study was to purify and characterize a hatching enzyme from starfish A. pectinifera for the development of a more value-added material.

\section{Methods}

\section{Starfish and reagents}

The adult starfish $A$. pectinifera was collected in July 2013 at Samcheok, Korea. About 500,000 live eggs were kept into $1 \mathrm{~L}$ of Kester artificial sea water (KASW salinity, $35.00 \%$; chlorinity, $19.00 \%$; pH 7.8) (Kester et al. 1967) and were dejellied by adjusting the $\mathrm{pH}$ 7.8 of KASW to 5.5 with $1 \mathrm{~N}$ of $\mathrm{HCl}$. After $10 \mathrm{~min}$, the supernatant was poured off and the precipitate was washed 3 or 4 times with the same volume of KASW. The sperms were collected out of the spermatophore artificially by pressing and were stored at $4{ }^{\circ} \mathrm{C}$ until inseminated. DEAE-sepharose fast flow and Sephacryl S-200 gels were purchased from Amersham Pharmacia Biotech (Uppsala, Sweden). Peptide- $N$-glycosidase F (PNGase F), dimethyl casein, trichloroacetic acid and tris (hydroxylmethyl) aminomethane were purchased from Sigma-Aldrich (St. Louis, MO, USA). All other chemicals and reagents that were used were of analytical grade.

\section{Preparation of crude hatching enzyme}

A crude hatching enzyme was prepared according to the method of Lepage (1989). Briefly, approximately 100,000 eggs in $500 \mathrm{ml}$ of KASW were inseminated by adding a few drops of $0.005 \%$ sperm, stirred at $16{ }^{\circ} \mathrm{C}$ overnight, and then precipitated using $70 \%$ ammonium sulfate at $4{ }^{\circ} \mathrm{C}$ overnight. After centrifuged at $7.728 \times g$ for $30 \mathrm{~min}$ (5810R; Eppendorf, Hamburg, Germany), the precipitate was dissolved in a $10 \mathrm{ml}$ of $0.02 \mathrm{M}$ Tris- $\mathrm{HCl}$ buffer $(\mathrm{pH}$ 7.4) and was then dialyzed against above buffer at $4{ }^{\circ} \mathrm{C}$ overnight. The egg membrane was prepared according to the modified method of Li (2006). About 5000 eggs were washed, stripped through $100 \mu \mathrm{m}$ mesh, and then squeezed using a syringe needle. After washed with distilled water, the egg membrane was sonicated at $35 \mathrm{kHz}$ for $10 \mathrm{~s}$ (MSONIC; Mirae Ultrasonic, Seoul, Korea). After centrifuged at $1.932 \times g$ for $15 \mathrm{~min}$, the collected egg membrane was washed with distilled water completely and was resuspended in a $10 \mathrm{ml}$ of $0.02 \mathrm{M}$ Tris- $\mathrm{HCl}$ buffer ( $\mathrm{pH} 7.4)$.

\section{Purification of hatching enzyme}

The crude starfish extract $(5 \mathrm{ml}, 30 \mathrm{mg} / \mathrm{ml})$ was loaded onto DEAE-Sepharose fast flow column $(2.6 \times 30.0 \mathrm{~cm})$, and then eluted with a linear gradient of $0-1 \mathrm{M} \mathrm{NaCl}$ in $0.02 \mathrm{M}$ Tris- $\mathrm{HCl}$ buffer $(\mathrm{pH}$ 7.4). The active fractions with more than $50 \%$ maximal activity were pooled and were then dialyzed against $0.02 \mathrm{M}$ Tris- $\mathrm{HCl}$ buffer $(\mathrm{pH}$ 7.4) overnight (DEAE active fraction). The DEAE active fraction was loaded onto Sephacryl S-200 gel filtration column $(2.6 \times 90 \mathrm{~cm})$, and then eluted with $0.1 \mathrm{M}$ Tris$\mathrm{HCl}$ containing $0.05 \mathrm{M} \mathrm{NaCl}(\mathrm{pH}$ 7.4). The active fractions with more than $50 \%$ maximal activity were pooled and were dialyzed against $0.02 \mathrm{M}$ Tris- $\mathrm{HCl}$ buffer $(\mathrm{pH}$ 7.4) overnight.

\section{Electrophoresis}

The hatching enzyme was evaluated by sodium dodecyl sulfate-polyacrylamide gel electrophoresis (SDS-PAGE) with $12 \%$ separating and $5 \%$ stacking gels. The molecular marker (ELPIS Bioteck Co., Taejeon, Korea) ranged from 35 to $170 \mathrm{kDa}$ was used to determine the molecular weight of hatching enzyme. The electrophoresized gel was stained using $0.05 \%$ Coomassie Blue R-250 (Bio-Rad Lavoratories, Hercules, CA, USA) and was destained in a destaining solution ( $40 \%$ methanol and $10 \%$ acetic acid).

\section{Deglycosylation of $\mathrm{N}$-glycans}

PNGase F was used to deglycosylate the N-linked carbohydrate from the glycoproteins or glycopeptides according to the method of Sanchez et al. (2007). Twenty microlitre of the starfish hatching enzyme $(200 \mu \mathrm{g})$ was added into $50 \mu \mathrm{l}$ of denaturing buffer $(0.5 \%$ SDS and $1 \% \beta$-mercaptoethanol) and was then boiled for $10 \mathrm{~min}$. After cooled down, $10 \mu \mathrm{l}$ of reaction buffer $(0.05 \mathrm{mM}$ phosphate, $\mathrm{pH} 7.5), 5 \mu \mathrm{l}$ of $15 \%$ TritonX-100, and $5 \mu \mathrm{l}$ of PNGase $\mathrm{F}(500 \mathrm{U} / \mathrm{ml})$ were added and then incubated at $37^{\circ} \mathrm{C}$ for $2 \mathrm{~h}$. The reaction was stopped by heating at $100{ }^{\circ} \mathrm{C}$ for $10 \mathrm{~min}$. Molecular weight of the de- $\mathrm{N}$-glycosylated hatching enzyme was calculated based on the results of SDS-PAGE.

\section{Protein assay}

Protein concentration of the hatching enzyme fractions was determined using Bradford method (1976). Bovine serum albumin (Sigma-Aldrich, St. Louis, MO, USA) was used as the calibration standard. The relative protein contents of chromatography fractions were estimated by measuring absorbance at $280 \mathrm{~nm}$.

\section{Choriolytic activity}

Choriolytic activity was determined according to the modified method of Yamagami (1972) using $10 \mathrm{mg} /$ $\mathrm{ml}$ egg membrane as the substrate. Each $100 \mu \mathrm{l}$ of the 
hatching enzyme and egg membrane $(10 \mathrm{mg} / \mathrm{ml})$ were mixed and incubated at $30{ }^{\circ} \mathrm{C}$ for $30 \mathrm{~min}$. The reaction was stopped by adding the cold TCA $(20 \% \mathrm{w} / \mathrm{v}, 2.8 \mathrm{ml})$. After centrifuged at $3000 \times g$ for $30 \mathrm{~min}$, the supernatant was collected. The absorbance of supernatant at $280 \mathrm{~nm}$ was measured using a spectrophotometer (V-300; JASCO, Seoul, Korea). One unit (U) of choriolytic activity was defined as an increase in absorbance by $0.001 / \mathrm{min}$ at $280 \mathrm{~nm}$.

\section{Proteolytic activity}

Proteolytic activity was determined using the determination method of choriolytic activity by substituting egg membrane with casein as the substrate. Each $100 \mu \mathrm{l}$ of the hatching enzyme and casein $(10 \mathrm{mg} / \mathrm{ml})$ were mixed and incubated at $30{ }^{\circ} \mathrm{C}$ for $30 \mathrm{~min}$. The reaction was stopped by adding the cold TCA ( $20 \% \mathrm{w} / \mathrm{v}, 2.8 \mathrm{ml})$. After centrifuged at $3000 \times g$ for $30 \mathrm{~min}$, the supernatant was collected. The absorbance of supernatant at $280 \mathrm{~nm}$ was measured using a spectrophotometer (V-300; JASCO). One unit (U) of proteolytic activity was defined as an increase in absorbance by $0.001 / \mathrm{min}$ at $280 \mathrm{~nm}$.

\section{Effects of $\mathrm{pH}$ and temperature on the proteolytic activity and stability of hatching enzyme}

The effect of $\mathrm{pH}$ profile on the proteolytic activity of hatching enzyme was determined at different ranges of $\mathrm{pH}$ 4.0-10.0: sodium acetic acetate buffer ( $\mathrm{pH} 4.0-6.0$ ), phosphate buffer ( $\mathrm{pH} 7.0-8.0$ ), and glycine- $\mathrm{NaOH}$ buffer (pH 9.0-10.0) (Li and Kim 2013). The effect of temperature on the enzyme activity was determined at different temperatures of $20-50{ }^{\circ} \mathrm{C}$. Casein was used as the substrate. The effect of $\mathrm{pH}$ on the hatching enzyme stability was determined by pre-incubating enzyme over a range of $\mathrm{pH} 4.0-10.0$ for $30 \mathrm{~min}$. Subsequently, the enzyme mixture was adjusted to $\mathrm{pH} 7.4$ using a $0.1 \mathrm{~N} \mathrm{NaOH}$ or $\mathrm{HCl}$. The effect of temperature on the enzyme stability was determined by pre-incubating the enzyme at $20-50{ }^{\circ} \mathrm{C}$ for $30 \mathrm{~min}$. The remaining proteolytic activity for hatching enzyme activity and stability was measured under the same condition as the determination of proteolytic activity described above. The relative activity was defined as the percentage of activity determined with respect to the maximum hatching enzyme activity.

\section{Determination of kinetic parameters}

The kinetic parameters $\left(K_{m}\right.$ and $\left.V_{\max }\right)$ of the purified enzyme were determined by measuring proteolytic activity at different concentrations of casein under the same condition as described above. $K_{m}$ and $V_{\max }$ were calculated from the Lineweaver-Burk plot. The $K_{c a t}$ and $K_{c a t} / K_{m}$ values were calculated based on the $K_{m}$ and $V_{\text {max }}$ values.
Effect of inhibitors and metal ions on the hatching enzyme activity

The effects of various inhibitors on the proteolytic activity of hatching enzyme were determined. Each $100 \mu \mathrm{l}$ of the hatching enzyme and casein $(10 \mathrm{mg} / \mathrm{ml})$ were mixed with inhibitors (5 mM for EDTA and EGTA, and $0.1 \mathrm{mM}$ for leupeptin, TLCK, TPCK and PMSF) and incubated at $30{ }^{\circ} \mathrm{C}$ for $30 \mathrm{~min}$. The reaction was stopped by adding the cold TCA $(20 \% \mathrm{w} / \mathrm{v}, 2.8 \mathrm{ml})$. After centrifuged at $3000 \times g$ for $30 \mathrm{~min}$, the supernatant was collected. The absorbance of supernatant at $280 \mathrm{~nm}$ was measured using a spectrophotometer (V-300; JASCO). In addition, the purified hatching enzyme was pre-incubated at $30{ }^{\circ} \mathrm{C}$ for $30 \mathrm{~min}$ in the absence and the presence of bivalent cations such as $\mathrm{Mg}^{2+}, \mathrm{Ca}^{2+}, \mathrm{Cu}^{2+}$, and $\mathrm{Zn}^{2+}$. Then, the remaining proteolytic activity was measured under the same condition as described above. The relative proteolytic activity of hatching enzyme pre-incubated with no inhibitors or metal ions was used as the control.

\section{Recovery effect of metal ions on the EDTA-pretreated hatching enzyme}

The hatching enzyme was pretreated with $10 \mathrm{mM}$ of EDTA at $4{ }^{\circ} \mathrm{C}$ for $30 \mathrm{~min}$. Afterwards, metal ions $\left(\mathrm{Mg}^{2+}\right.$, $\mathrm{Ca}^{2+}, \mathrm{Cu}^{2+}$, and $\mathrm{Zn}^{2+}$ ) at $5 \mathrm{mM}$ were added and the enzyme mixture was incubated at $4{ }^{\circ} \mathrm{C}$ for $3 \mathrm{~h}$. The proteolytic activity was measured under the same condition as described above. The relative proteolytic activity of hatching enzyme pre-incubated with no metal ions was used as the control.

\section{Statistical analysis}

Experimental results were tested in triplicates and presented as mean values \pm standard error (SD).

\section{Results and discussion}

\section{Purification of the starfish hatching enzyme}

Hatching enzyme of starfish was purified using an ammonium sulfate precipitation, DEAE-Sepharose ion exchange and Sephacryl S-200 gel filtration column chromatograpy, in that order. DEAE-Sepharose ion exchange column chromatography resulted in two protein peaks with choriolytic activity (Fig. 1a). The yield, specific choriolytic activity, and purification ratio of peak I and II were 33.37 and $46.28 \%$, 30.22 and $23.76 \mathrm{U} / \mathrm{mg}$, and 2.59 and 2.04 fold, respectively (Table 1). Because of higher specific choriolytic activity, the peak I was further purified using a Sephacryl S-200 column chromatography, which resulted in only one protein peak (Fig. 1b). The purification rate, yield, and specific choriolytic activity of the purified hatching enzyme were 6.34 fold, $5.04 \%$, and $73.87 \mathrm{U} / \mathrm{mg}$, respectively (Table 1 ). The hatching enzyme with molecular weight of $86 \mathrm{kDa}$ was homogeneous on the SDS-PAGE (Fig. 2a). The specific 

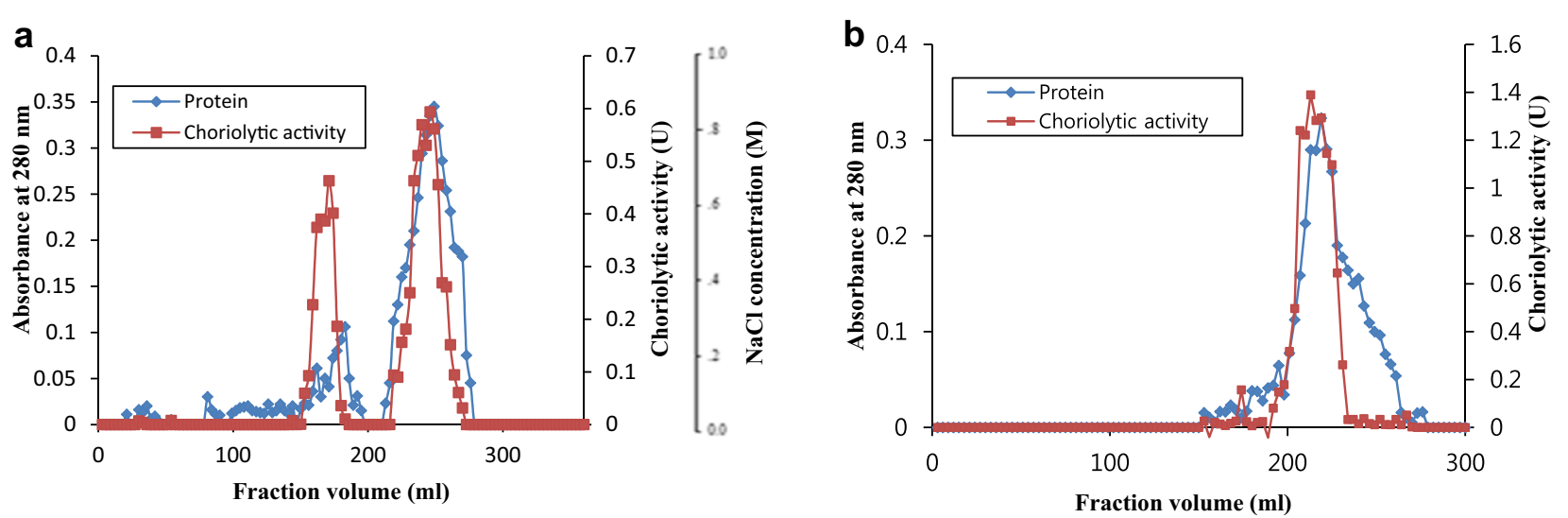

Fig. 1 Elution profile of the starfish hatching enzyme. a DEAE-lon exchange chromatography. b Sephachryl gel filtration chromatography

Table 1 Purification of hatching enzyme from starfish Asterinapectinifera

\begin{tabular}{llcccc}
\hline Purification step & $\begin{array}{l}\text { Total protein } \\
\text { (mg) }\end{array}$ & Total choriolyticactivity (U) & $\begin{array}{l}\text { Specificchoriolytic } \\
\text { activity (U/mg) }\end{array}$ & $\begin{array}{c}\text { Yield (\%) } \\
\text { (fold) }\end{array}$ \\
\hline $\begin{array}{l}\text { Hatching crude } \\
\text { lon exchange }\end{array}$ & 94.21 & 1098.50 & 11.66 & 100 & 1 \\
$\quad$ Peak I & 12.13 & 366.60 & 30.22 & 33.37 \\
Peak II & 21.4 & 508.40 & 23.76 & 46.28 \\
$\begin{array}{l}\text { Gel filtration } \\
\text { Peak I }\end{array}$ & 0.75 & 55.40 & 73.87 & 2.04 \\
\hline
\end{tabular}

choriolytic activity $(73.87 \mathrm{U} / \mathrm{mg}$ ) of the starfish hatching enzyme in this study was lower than $400.00 \mathrm{U} / \mathrm{mg}$ of brine shrimp (Fan et al. 2010) and $449.62 \mathrm{U} / \mathrm{mg}$ of starfish A. amurensis (Li and Kim 2013). The purification rate and yield of starfish hatching enzyme (6.34 fold and 5.04\%) in this study were also lower than those of starfish $\mathrm{A}$. amurensis (7.42 fold and $14.28 \%$ ) (Li and Kim 2013), shrimp (48.05 fold and $44.29 \%$ ) (Li et al. 2006), sea urchin (201 fold and $53 \%$ ) (Roe and Lennarz 1990), and sea squirt (67.8 fold and 29.4\%) (D'Aniello et al. 1997). These differences might be due to different species, preparations, and purification methods. The molecular weight of the starfish hatching enzyme in this study was $86 \mathrm{kDa}$, which was a smaller than $110.9 \mathrm{kDa}$ of $A$. amurensis (Li and Kim 2013), but a little higher than $73.3 \mathrm{kDa}$ of brine shrimp (Fan et al. 2010). However, it was much higher than those of the hatching enzyme from shrimp ( $43 \mathrm{kDa}$ ) (Li et al. 2006), sea urchin (37, 44, $51 \mathrm{kDa}$ ) (Lepage and Gache 1989; Nomura et al. 1991; Takeuchi et al. 1979), frog (40, $56 \mathrm{kDa}$ ) (Fan and Katagiri 2001; Kitamura and Katagiri 1998), sea squirt (34 kDa) (D'Aniello et al. 1997), flounder (34.8 kDa) (Shi et al. 2010), Fundulus heteroclitus (15-40 kDa) (DiMichele et al. 1981), Oryzias latipes (LCE $25.5 \mathrm{kDa}$; HCE $24 \mathrm{kDa}$ ) (Yasumasu et al. 1989a, b), and Salmo gairdneri (10 kDa) (Hagenmaier 1974). The PNGase F was used to release the asparagine-linked (N-linked) oligosaccharides from the hatching enzyme protein. After PNGase F treatment, the band of hatching enzyme protein with $86 \mathrm{kDa}$ was shifted to $62 \mathrm{kDa}$ (Fig. 2b). Therefore, the $24 \mathrm{kDa}$ of N-linked oligosaccharides was removed from the hatching enzyme protein. The molecular weight of the starfish hatching enzyme, $86 \mathrm{kDa}$, was quietly different from those of other animals (shrimp, sea urchin, frog, sea squirt, flounder, mummichog, medaka, and rainbow trout) including $110.9 \mathrm{kDa}$ of starfish Asterias amurensis. In addition, Tbrain or T-box brain protein 1 is a transcription factor protein important in vertebrate embryo development. It is encoded by the TBR1 gene which is involved in the mesoderm formation of vertebrate embryos. Mammalian T-brain is expressed in the developing central nervous system. Hinman et al. (2007) reported the results of gene analysis of sea stars and sea urchins as follows; it has been conserved for 500 million years since sea stars and sea urchins last shared a common ancestor. Amid this high level of conservation, one significant regulatory change was elucidated. Tbrain was required for correct otx $\beta 1 / 2$ expression in the sea star, but not in the sea urchin. In sea urchin, Tbrain was not co-expressed with otx $\beta 1 / 2$ and instead had an essential role in specification of the embryonic skeleton. Tbrain in these echinoderms was 


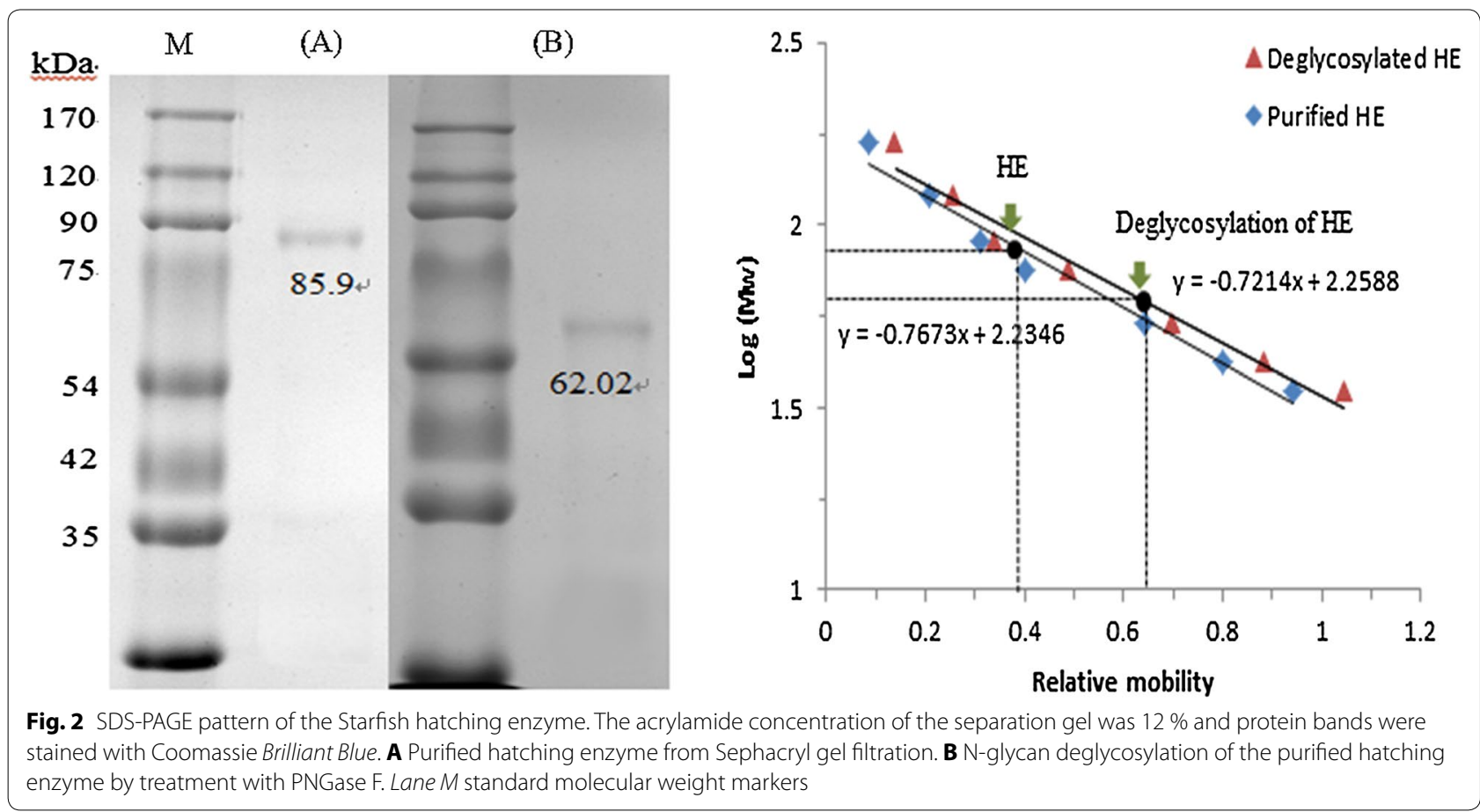

thus a perfect example of an orthologous gene co-opted for entirely different developmental processes. According to above explanations, the starfish hatching enzyme might be ortholog.

\section{Effect of $\mathrm{pH}$ and temperature on the hatching enzyme activity and stability}

The starfish hatching enzyme exhibited a higher activity in the range of $\mathrm{pH} 6.0-9.0$ and maximum activity at $\mathrm{pH} 7.0$ (Fig. 3). This enzyme was stable at $\mathrm{pH}$ 6.0-9.0 and had the maximum stability at $\mathrm{pH} 8.0$ (Fig. 3). The maximum activity $\mathrm{pH}$ (7.0) of the starfish hatching enzyme in this study was the same as $\mathrm{pH} 7.0$ of brine shrimp and lower than those of the hatching enzyme of sea urchin (pH 8.0) (Roe and Lennarz 1990; Li and Kim 2014), A. amurensis ( $\mathrm{pH}$ 8.0) ( $\mathrm{Li}$ and Kim 2013), O. latipes (LCE pH 8.6; HCE pH 8.0, 8.7) (Yasumasu et al. 1989a, b), $S$. gairdneri (pH 8.0-8.5) (Hagenmaier 1974), sea squirt (pH 8.5) (D’Aniello et al. 1997), quail (pH 9.0) (Iwasawa et al. 2009), but higher than $\mathrm{pH} 6.0$ of the shrimp hatching enzyme ( $\mathrm{Li}$ et al. 2006). The optimal activity temperature of the starfish hatching enzyme was $40{ }^{\circ} \mathrm{C}$ (Fig. 3), whereas its maximum stability temperature was $20{ }^{\circ} \mathrm{C}$ (Fig. 3). The optimal activity temperature of the starfish hatching enzyme was the same as $40{ }^{\circ} \mathrm{C}$ of the sea urchin (Nomura et al. 1991), brine shrimp (Fan et al. 2010), and shrimp (Li et al. 2006), but higher than $30^{\circ} \mathrm{C}$ of frog (Roe and Lennarz 1990; Kester et al. 1967), O. latipes (Yasumasu et al. 1989a, b), and A. amurensis (Li and Kim
2013). These stable $\mathrm{pH}$ and temperature of the starfish hatching enzyme are important to skincare because the acidic $\mathrm{pH}(4.4-5.6)$ and the imbalance change in skin permit for normal exfoliation of surface dead cells well (Natalia and Varinia 2010). Furthermore, in the early state of injury or wound healing, the considerable fibrinogen from the liver is deposited as fibrin or fibronectin on the gap of the damage part (Brown et al. 1993). Meanwhile, the dermal fibroblasts begin to cluster to this fibrin matrix, over-accumulate collagen and then built the skin contraction as collagen-like tissue (Clark 1993). Hence, the over-accumulation of collagen is responsible for the unsmooth skin of scar or keloid. Li and Kim (2014) reported that the A. ammurensis starfish hatching enzyme had comparable ability to collagenase and $\alpha$-chymotrypsin, which degraded collagen and fibrinogen efficiently. In addition, the $A$. ammurensis starfish hatching enzyme had the potential application to remove the matrix composition in scar or keloid tissue. It is generally known that the temperature and $\mathrm{pH}$ of human skin are $28-32{ }^{\circ} \mathrm{C}$ and $\mathrm{pH} 7.0$, respectively (Plasencia et al. 2007). Therefore, the $A$. pectinifera starfish hatching enzyme which was very stable at $\mathrm{pH} 7.0$ and $20-30{ }^{\circ} \mathrm{C}$ might have a potential for the development of a skin care product.

\section{Effects of chelators, inhibitors, and metal ions on the enzyme activity}

The effects of chelators, inhibitors, and metal ions on the enzyme activity are shown in Table 2. EDTA and EGTA 

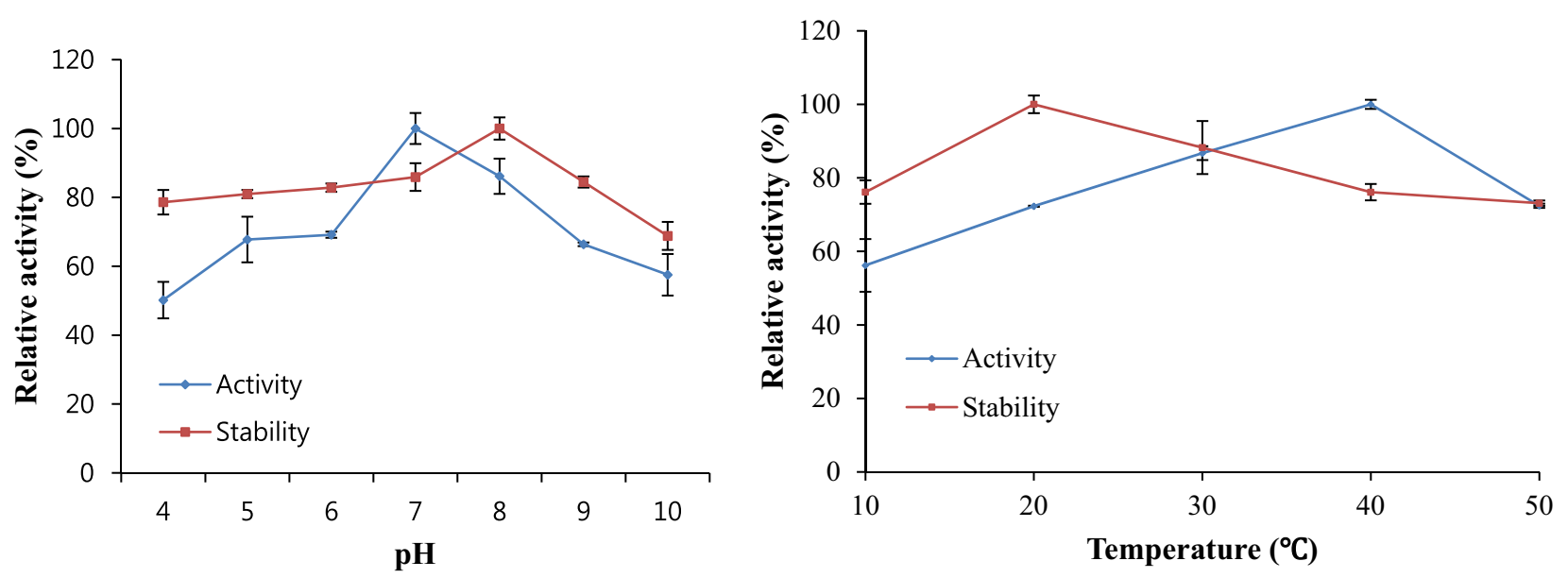

Fig. 3 Effects of pH and temperature on the proteolytic activity and stability of hatching enzyme

Table 2 Effect of metal ions and inhibitors on the proteolyticactivity of hatching enzyme

\begin{tabular}{llc}
\hline Inhibitors or metal ions & Concentration (mM) & Relative activity (\%) \\
\hline EDTA & 5 & $38.15 \pm 9.86$ \\
EGTA & 5 & $42.31 \pm 8.41$ \\
$\mathrm{Cu}^{2+}$ & 10 & $75.38 \pm 7.01$ \\
$\mathrm{Mg}^{2+}$ & 10 & $71.22 \pm 4.65$ \\
$\mathrm{Zn}^{2+}$ & 10 & $167.28 \pm 12.69$ \\
$\mathrm{Ca}^{2+}$ & 10 & $86.47 \pm 2.50$ \\
Leupeptin & 0.1 & $56.29 \pm 2.57$ \\
PMSF & 0.1 & $56.20 \pm 4.15$ \\
TLCK & 0.1 & $56.72 \pm 2.34$ \\
TPCK & 0.1 & $40.47 \pm 8.40$ \\
\hline
\end{tabular}

inhibited significantly the proteolytic activity of hatching enzyme by more than $50 \%$ (Table 2), which was similar to the results of the frog (Fan and Katagiri 2001), flounder (Shi et al. 2010), sea squirt (D’Aniello et al. 1997), A. amurensis (Li and Kim 2013), and sea urchin (Roe and Lennarz 1990). The proteolytic activity of hatching enzyme was strongly activated by $167.28 \%$ at $5 \mathrm{mM}$ of $\mathrm{Zn}^{2+}$ (Table 2). $\mathrm{Zn}^{2+}$ also recovered the denatured hatching enzyme activity more greatly than other ion metals (Fig. 4), which was similar to the hatching enzymes of the brine shrimp (Fan et al. 2010), sea squirt (D'Aniello et al. 1997), A. amurensis ( $\mathrm{Li}$ and Kim 2013) and shrimp (Li et al. 2006). Based on the inhibitory activity of EDTA and EGTA, the starfish hatching enzyme in this study was characterized as metalloprotease, which was similar to the hatching enzymes of sea squirt (D'Aniello et al. 1997) and sea urchin (Roe and Lennarz 1990). TLCK and TPCK are known to inhibit trypsin and chymotrypsin through the alkylation of a histidine residue at active sites, whereas PMSF and leupeptin inhibit them by sulfonylating the hydroxyl group of the serine residue at the active site, respectively (Ikegami et al. 1994). The starfish hatching enzyme was sensitive to EDTA and several metal ions (Table 2). $\mathrm{Zn}^{2+}$ recovered the proteolytic activity of starfish hatching enzyme pretreated with EDTA. Therefore, it was indicated that starfish hatching enzyme might be also a kind of $\mathrm{Zn}^{2+}$-protease, which was similar to the results of hatching enzymes from frog (Fan and Katagiri 2001; Kitamura and Katagiri 1998), O. latipes (Yasumasu et al. 1989a, b), brine shrimp (Fan et al. 2010), flounder (Shi et al. 2010), shrimp (Li et al. 2006), sea squirt (D’Aniello et al. 1997), A. amurensis (Li and Kim 2013), F. heteroclitus (DiMichele et al. 1981), sea urchin (Yasumasu et al. 1989), and pike (Schoot and Denuce 1981). Based on these results, the A. pectinifera starfish hatching enzyme was classified as a serine-zinc protease.

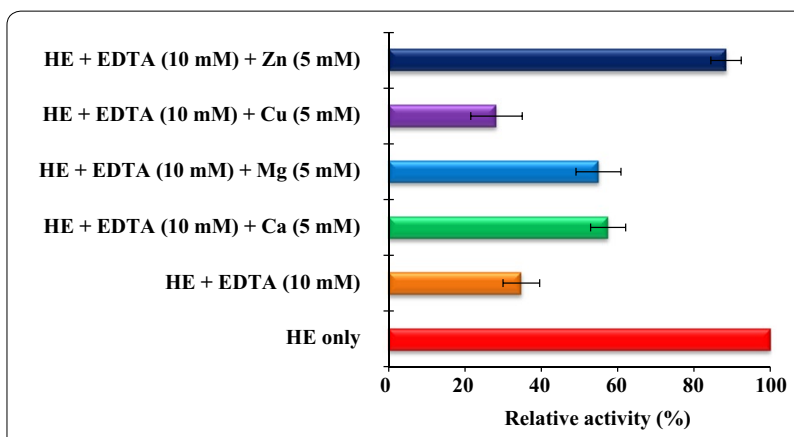

Fig. 4 Recovery effect of metal ions on the EDTA pretreated starfish hatching enzyme 

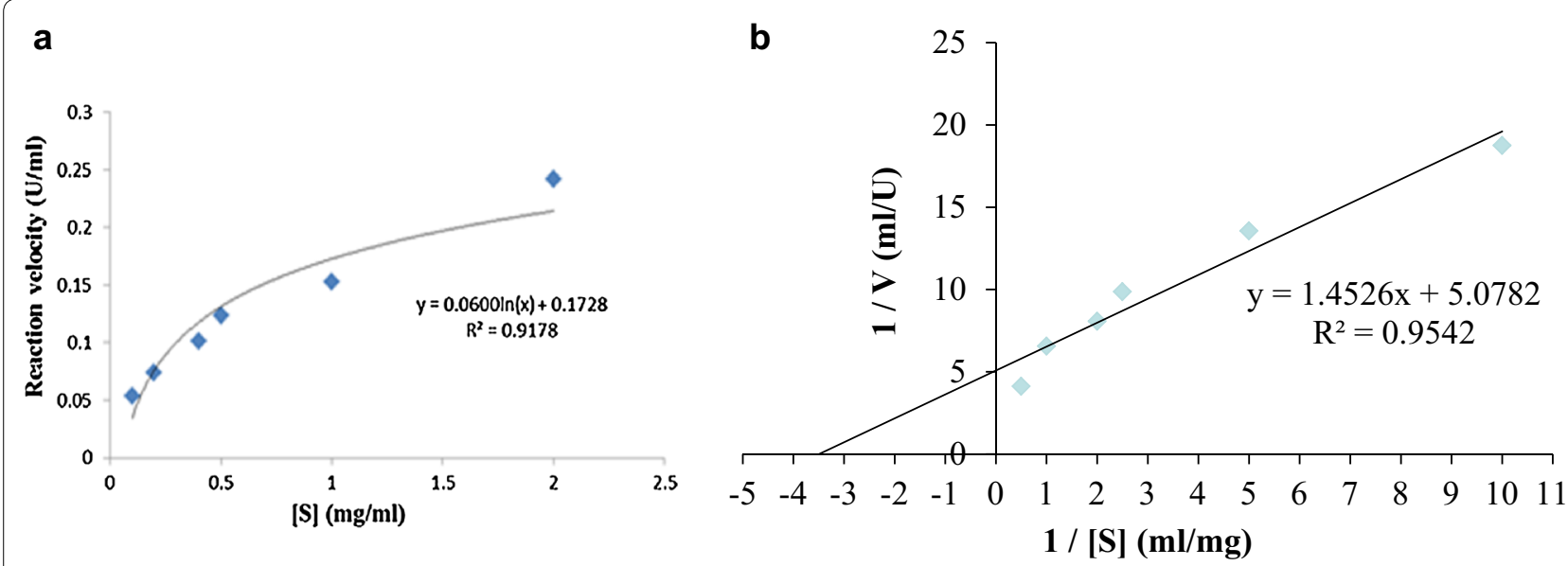

Fig. 5 Michaelis-Menten kinetic curve $\mathbf{a}$ and Lineweaver-Bulk plots $\mathbf{b}$ of the starfish hatching enzyme

\section{Kinetic parameters}

The kinetic parameters $\left(K_{m}, V_{\max }\right)$ of the purified hatching enzyme were determined by measuring proteolytic activity at different concentrations of casein (Fig. 5). The $K_{m}, V_{\text {max }}, K_{c a t}$, and $K_{c a t} / K_{m}$ values of the starfish hatching enzyme were $0.289 \mathrm{mg} / \mathrm{ml}, 0.197 \mathrm{U} / \mathrm{ml}, 112.57 \mathrm{~s}^{-1}$, and $389.52 \mathrm{ml} / \mathrm{mg}$ s, respectively. $K_{m}$ value $(0.289 \mathrm{mg} / \mathrm{ml})$ of the starfish hatching enzyme on casein was lower than $8.20 \mathrm{mg} / \mathrm{ml}$ of brine shrimp (Fan et al. 2010), $7.47 \mathrm{mg} /$ $\mathrm{ml}$ of shrimp (Li et al. 2006), $4.28 \mathrm{mg} / \mathrm{ml}$ of flounder (Shi et al. 2010), and $0.31 \mathrm{mg} / \mathrm{ml}$ of starfish A. amurensis (Li and Kim 2013), whereas higher than $0.2 \mathrm{mg} / \mathrm{ml}$ of frog (Fan and Katagiri 2001) and $0.12 \mathrm{mg} / \mathrm{ml}$ of sea urchin (Roe and Lennarz 1990). The diversities of the $K_{m}$ value may be correlated with the difference in species, survival environments, enzyme structures, and ion concentrations as well. The less $K_{m}$ value means the higher affinity of enzyme to substrate (Ranaldi et al. 1999). Therefore, it was thought that the starfish hatching enzyme might be efficient for the degradation of collagen.

\section{Conclusions}

A novel hatching enzyme with $86 \mathrm{kDa}$ of molecular weight was purified from starfish (A. pectinifera). De$N$-glycosylation of the enzyme leads to a loss of $24 \mathrm{kDa}$ as observed by the migration behavior in SDS-PAGE. The purification rate and yield of starfish hatching enzyme were 6.34 fold and $5.04 \%$, respectively. The optimal $\mathrm{pH}$ and temperature of hatching enzyme activity were 7.0 and $40{ }^{\circ} \mathrm{C}$, respectively, while those of stability were $\mathrm{pH}$ 7.0 and $20{ }^{\circ} \mathrm{C}$. The starfish hatching enzyme was classified was a serine-zinc protease. Therefore, the $A$. pectinifera hatching enzyme might be utilized as a cosmeceutical because its optimum $\mathrm{pH}$ and temperature stability were similar to those of human skin.
Authors' contributions

$J \mathrm{HC}$, a first author, carried out the purification and characterization of starfish hatching enzyme, participated in the sequence alignment, and drafted the manuscript. SMK, a corresponding author, participated in its design and coordination, and helped to draft the manuscript. Both authors read and approved the final manuscript.

\section{Acknowledgements}

This research was partially supported by the Korea Sea Grant Program (GangWon Sea Grant) funded by the Ministry of Oceans and Fisheries in Korea.

\section{Competing interests}

The authors declare that they have no competing interests.

Received: 3 August 2015 Accepted: 6 October 2016

Published online: 22 November 2016

\section{References}

Ala-Kokko L, Rintala A, Savolainen ER (1987) Collagen gene expression in keloids: analysis of collagen metabolism and type I. III, IV, and V procollagen mRNAs in keloid tissue and keloid fibroblast cultures. J Invest Dermatol 89:238-244

Barkhouse CL, Nile M, Davidson LA (2007) A literature review of sea star control methods for bottom and off bottom shellfish cultures. Can Ind Rep Fish Aquat Sci. 279:38

Brandford MM (1976) A rapid and sensitive method for the quantitation of microgram quantities of protein utilizing the principle of protein-dye binding. Anal Biochem 72:248-254

Brown LF, Lanir N, McDonagh J, Tognazzi K, Dvorak AM, Dvorak HF (1993) Fibroblast migration in fibrin gel matrices. Am J Pathol 142:273-283

Clark RA (1993) Regulation of fibroplasia in cutaneous wound repair. Am J Med Sci 306:42-48

D’Aniello A, De Vinectiis M, Di Fiore MM, Scippa S (1997) Hatching enzyme from the sea-squirt Ciona intestinalis: purification and properties. Biochim Biophys Acta 1339:101-112

DiMichele L, Taylor MH, Singleton R (1981) The hatching enzyme of Fundulusheteroclitus. J Exp Zoolog. 216:133-140

Fan TJ, Katagiri C (2001) Properties of hatching enzyme from Xenopus laevis. Eur J Biochem 268:4892-4898

Fan T, Wang J, Yuan W, Zhong Q, Shi Y, Cong R (2010) Purification and characterization of hatching enzyme from brine shrimp Astermia salina. Acta Biochim Biophys Sin 42:165-171 
Hagenmaier HE (1974) The enzymological properties of a highly purified enzyme (chorionase) from the hatching fluid of the rainbow trout, Salmogairdnen. Comp. Biochem. Physiol. B. 49(1974):313-324

Hinman VF, Nguyen A, Davidson EH (2007) Caught in the evolutionary act: precise cis-regulatory basis of difference in the organization of gene networks of sea stars and sea urchin. Dev Bio. 312:584-595

Ikegami S, Kobayashi H, Myotoshi Y, Ohta S, Kato KH (1994) Selective inhibition of exoplasmic membrane fusion in echinoderm gametes with jaspisin, a novel antihatching substance isolated from a marine sponge. J Biol Chem 269:23262-23267

Iwasawa A, Mao KM, Yasumasu S, Yoshizaki N (2009) A possible role of chorion protease in shell membrane degradation during development of quail embryos. Poult Sci 88:2636-2643

Kester DR, Duedall IW, Connors DN, Pytkowicz RM (1967) Preparation of artificial seawater. Limnol Oceanogr 12:176-179

Kitamura Y, Katagiri C (1998) Characterization of the hatching enzyme from embryos of an anuran amphibian, Ranapirica. Biochim Biophys Acta 1387:153-164

Kudo N, Yasumasu S, luchi I, Tanokura M (2004) Crystallization and preliminary X-ray analysis of HCE-1, a hatching enzyme of medaka fish, Oryzias latipes. Acta Crystallogr D Biol Crystallogr 60:725-726

Kurihara T (1999) Effects of sediment type and food abundance on the vertical distribution of the starfish Asterina pectinifera. Mar Ecol Prog Ser 181:269-277

Lepage T, Gache C (1989) Purification and characterization of the sea urchin embryo hatching enzyme. J Biol Chem 264:4787-4793

Li ZJ, Kim SM (2013) A novel hatching enzyme from starfish Asterias amurensis: purification, characterization, and cleavage specificity. Appl Biochem Biotechnol 169(4):1386-1396

Li ZJ, Kim SM (2014a) Structural identification and proteolytic effects of the hatching enzyme from starfish Asterias amurensis. Protein Pept Lett 21:631-638

Li ZJ, Kim SM (2014b) The application of the starfish hatching enzyme for the improvement of scar and keloid based on the fibroblast-populated collagen lattice. Appl Biochem Biotechnol 173:989-1002

Li B, Fan T, Yang L, Chong R, Li L, Sun W, Chui-xian L, Shi Z (2006) Purification and characterization of hatching enzyme from shrimp Penaeus chinensis. Arch Biochem Biophys 451:188-193

Natalia M, Varinia M (2010) Milady's skin care and cosmetic ingredients dictionary, 3rd edn. Thomason Learning, Canada

Nomura K, Tanaka H, Kikkawa Y, Yamaguchi M, Suzuki N (1991) The specificity of sea urchin hatching enzyme (envelysin) places it in the mammalian matrix metalloproteinase family. Biochemistry 30:6115-6123
Plasencia I, Norlen L, Bagatolli A (2007) Biolphys J 93:3142-3155

Ranaldi F, Vanni P, Giachetti E (1999) What students must know about the determination of enzyme kinetic parameters. Biochem Educ 27:87-91

Roe JL, Lennarz WJ (1990) Biosynthesis and secretion of the hatching enzyme during sea urchin embryogenesis. J Biol Chem 265:8704-8711

Sanchez EF, Gabriel LM, Gontijo S, Gremski LH, Veiga SS, Evangelista KS, Eble JA, Richardson M (2007) Richardson structural and functional characterization of a P-III metalloproteinase, leucurolysin-B, from Bothrops leurus venom. Arch Biochem Biophys 468(2):193-204

Sawada H, Yamazaki K, Hoshi M (1990) Trypsin-like hatching protease from mouse embryos: evidence for the presence in culture medium and its enzymatic properties. J Exp Zool 254:83-87

Schoot AFM, Denuce JM (1981) Purification and characterization of hatching enzyme of the pike Esox lucius. Int J Biochem 13:591-602

Shi ZP, Fan TJ, Cong RS, Wang XF, Sun WJ, Yang LL (2010) Purification and characterization of hatching enzyme form flounder Paralichthys olivaceus. Fish Physiol Bio Chem 32:35-42

Takeuchi K, Yokosawa H, Hosi M (1979) Purification and characterization of hatching enzyme of Strongylocentrotus intermedius. Eur J Biochem 100:257-565

Urch UA, Hedrick JL (1981) Isolation and characterization of the hatching enzyme from the amphibian, Xenopus laevis. Arch Biochem Biophys 206:424-431

Yamagami K (1972) A method for rapid and quantitative determination of the hatching enzyme (chorionase) activity of the medaka, Oryzias latipes. Dev Biol 29(3):343-348

Yasumasu S, luchi I, Yamagami K (1989a) Purification and partial characterization of high choriolytic enzyme (HCE), a component of the hatching enzyme of the teleost Oryzias latipes. J Biochem 105:204-211

Yasumasu S, luchi I, Yamagami K (1989b) Isolation and some properties of low choriolytic enzyme (LCE), a component of the hatching enzyme of the hatching enzyme of the teleost Oryzias latipes. J Biochem 105:212-218

Yasumasu S, Mao KM, Sultana F, Sakaguchi H, Yoshizaki N (2005) Cloning of a quail homologue of hatching enzyme: its conserved function and additional function in egg envelope digestion. Dev Genes Evol 215:489-498

Young AR, Mancuso NE, Meeusen N, Bowles VM (2000) Characterization of proteases involved in egg hatching of the sheep blowfly, Lucilia cuprina. Int J Parasitol 30:925-932

\section{Submit your manuscript to a SpringerOpen ${ }^{\circ}$ journal and benefit from:}

- Convenient online submission

- Rigorous peer review

- Immediate publication on acceptance

- Open access: articles freely available online

- High visibility within the field

- Retaining the copyright to your article

Submit your next manuscript at $\boldsymbol{\nabla}$ springeropen.com 